\title{
Perspektif Remaja Terhadap Dakwah Online Studi Empiris Pada Siswa MA Hasanuddin Siraman Kesamben Blitar
}

\author{
Wihda Ikvina Anfaul Umat \\ Pesantren Riset Al-Muhtada \\ Email :wihdaikvina@gmail.com \\ Khoirul Mumtahanah \\ Pesantren Riset Al-Muhtada \\ Email : khoirul.mumtahanah@gmail.com
}

\begin{tabular}{|c|c|}
\hline $\begin{array}{l}\text { Submission } \\
\text { Track: }\end{array}$ & Abstract \\
\hline Received: & $\begin{array}{l}\text { Judging from the times, we will increasingly understand that life goes fast. Good } \\
\text { filter ability is a key indicator that everyone must have in facing this development. }\end{array}$ \\
\hline 3 februari 2020 & $\begin{array}{l}\text { This article is the result of research that leads to the development of the digital } \\
\text { world, especially in the field of online that touches almost all aspects of life. One }\end{array}$ \\
\hline Final Revision: & at attracts researchers is the entry of the online world into the realm of da'wah. \\
\hline 15 Maret 2020 & $\begin{array}{l}\text { Conventional da'wah is done face-to-face, now has experienced many shifts and } \\
\text { shifts through online media with the intention of facilitating access. The purpose }\end{array}$ \\
\hline Available online: & $\begin{array}{l}\text { of writing this article is to analyze adolescent perceptions about online propaganda } \\
\text { and preaching methods that are of interest to adolescents with empirical studies of }\end{array}$ \\
\hline 25 Maret 2020 & $\begin{array}{l}\text { MA students Hasanuddin Siraman, Kesamben, Blitar. This descriptive-qualitative } \\
\text { article directly observes adolescents at MA Hasanuddin about their perceptions of }\end{array}$ \\
\hline Corresponding & $\begin{array}{l}\text { online da'wah and the method of da'wah that appeals to adolescents. The selection } \\
\text { of adolescents as research subjects is because researchers find data that users of }\end{array}$ \\
\hline Author: & $\begin{array}{l}\text { the digital or online world are the most widely held by adolescents, so that } \\
\text { indirectly adolescents have the possibility of accessing da'wah online. The method }\end{array}$ \\
\hline Name \& E-mail Address & $\begin{array}{l}\text { used for this research is observation, interview, and documentation. The data } \\
\text { obtained will then be matched using data triangulation techniques to be able to }\end{array}$ \\
\hline Umi Sholehah & $\begin{array}{l}\text { obtain data validity. The results of this study in the form of adolescent perceptions } \\
\text { of online propaganda and propaganda methods are in demand by adolescents in }\end{array}$ \\
\hline
\end{tabular}

\section{Keywords: Online Media, Da'wah, Youth}

\section{PENDAHULUAN}

Membicarakan tentang majunya zaman, memang menjadi satu topik yang sangat menarik untuk dibahas, pasalnya, kemajuan zaman telah juga berdampak pada hampir seluruh aspek yang bersentuhan dengan kegiatan sehari-hari. Salah satu kemajuan yang memiliki eksistensi cukup menarik adalah Internet. Internet merupakan kebaharuan dalam dunia digital yang mana seluruh dunia dapat terakses melalui informasi berbentuk visual, audio, maupun audio visual. Internet telah sangat mudah merambahi seluruh aspek dalam kehidupan, dan membantu banyak pekerjaan serta kebutuhann sehari hari, mulai dari aspek ekonomi untuk promosi dan berjualan, sampai pada kegiatan kependidikan digunakan sebagai sumber belajar siswa juga mahasiswa. Internet sangat mudah untuk diakses oleh segala usia sehingga kehadirannya mau tidak mau memang diakui membawa banyak manfaat.

Bergesar sedikit dari permasalahan terkait dengan internet dan dunia digital. Penulis mengajak pembaca untuk membicarakan mengenai dakwah yang secara Istilah oleh Syeh Ali Mahfud dalam Zulkarnaini (2015) diartikan sebagai usaha untuk mendorong manusia agar berbuat kebajikan dan petunjuk, menyuruh mereka berbuat yang maruf dan 
melarang yang munkar agar mendapat kebahagian tidak hanya di dunia namun juga di akhirat. Dakwah juga secara mudah dapat diartikan sebagai suatu ajakan untuk melakukan kebaikan. Dakwah adalah salah satu cara untuk menyerukan kebaikan yang dulu oleh Rasullah digunakan untuk mengajak kaum kafir Quraisy masuk kedalam ketauhidan untuk menyembah Allah sebagai satu satunya zat terkuat dan paling kuasa di seluruh alam. Dahulu nabi menggunakan pendekatan personal dengan menyampaikan ajakan-ajakan keislaman melalui rumah ke rumah dan secara langsung, begitu hal tersebut diikuti oleh sahabat sahabat dan ulama ulama selanjutnya. Sampai saat ini pun masih banyak ulama yang menggunakan cara nabi, namun tentu dengan lebih terbuka. Satu hal yang menurut penulis baru dan mulai ada setelah kemajuan zaman khususnya setelah Internet hadir adalah penyebaran dakwah yang dilakukan dengan menggunakan media berbasis Online, sehingga setiap orang bisa mengakses dakwah dimanapun.

Berkaitan dengan dakwah online yang kini banyak terlihat di berbagai platform media sosial, dapat dilihat sebagai kemajuan yang baik sebab kemudahan yang ditawarkan dalam penyajiannya, namun, tidak sepenuhnya dampak yang dimunculkan adalah baik, namun juga terdapat beberapa dampak negatif yang bisa mucul. Intrenet adalah satu media informasi yang dapat mengunduh serta mengunggah segala macam berita dan informasi, tanpa diketahui seberapa besar keakuratan serta kevalidan data yang disajikan. Jika dakwah diletakkan di platformplatform internet maka, dapat pula terjadi ketidakvaidan data dan informasi yang diunggah. Hal tersebut tentu dapat berpotensi melahirkan hoax dan pengrusakan terhadap informasi sebenarnya. Lebih dari itu, orang yang masih awam dan baru saja mempelajari tentang agama tentu saja bisa sangat mudah terombang ambingkan oleh informasi yang diterimanya.

Media internet mau tidak mau memaksa penggunanya untuk menjadi bijak dan selektif dalam memilih dan memilah informasi yang ada, tentu dengan masih adanya beberapa website yang tidak teridentifikasi keabsahannya perlu dengan sangat hati hati melihatnya. Begitu juga dengan dakwah online yang banyak menyebar tentu harus ada sikap kehatihatian yang ditanamkan.

Menilik pada data yang ada, tingkat penggunaan media online di Indonesia sudah menginjak prosentase yang cukup tinggi, dan sebagian pengaksesnya adalah remaja. Cukup aktif dalam menggunakan dunia online sedikit banyak remaja telah mengetahui adanya informasi mengenai dunia dakwah yang merambah kedalamnya, beberapa ada yang menjadi penonton akttif, beberapa ada yang menjadi penonton pasif dan sangat jarang melihat fenomena dakwah online dan sebagian lain juga merasa acuh dengan keberadaan dakwah online. Jika dinilai secara sebjektif dakwah ini menjadi cukup penting untuk menumbuhkan jiwa religiusitas di dalam diri mereka yang masih dalam masa pertumbuhan dan perkembangan. Suntikan-suntikan rohaniah merupakan salah satu aspek yang bisa saja menjadi pengaruh pada karakter dan perilaku mereka sehari-hari. Dakwah juga dapat dijadikan sebagai tuntunan para remaja untuk pedoman dalam beribadah, berakidah dan bermuamalah. Sebab dakwah juga mengandung nilai-nilai yang bersumber dari Al-Quran dan juga Hadist serta tafsir dari keduanya yang diasosiasikam dengan kehidupan sehari hari. Dengan menonton dan mendengarkan 
dakwah secara kontinu tentu akan dapat membawa perubahan yang baik bagi remaja terlebih jika nilai baik dalam dakwah dapat diimplemetasikan dalam kehidupan sehari-hari.

Berdasar atas pernyataan peryataan diatas, artikel ini ingin membahas bagaimana persepsi dari para remaja mengenai dakwah online yang kini banyak disajikan. Mengingat remaja adalah usia yang memiliki pandangan yang cukup beragam dalam menilai sesuatu, juga kritis dalam menyikapi hal hal yang baru. Penulis hendak mengetahui bagaimana saja persepsi yang muncul dari para remaja terkait dengan adanya dakwah online yang kian hari, kian meluas. Selain ingin menjelaskan mengenai persepsi, tulisan ini juga hendak menguraikan tentang tema apa saja yang disukai oleh para remaja ketika mendengarkan dakwah. Hal tersebut dimaksudkan untuk menyajikan dakwah sesuai dengan kesenangan mereka. Sehingga dakwah menjadi atraktif dan menarik untuk disimak bagi remaja.

Artikel ini hendak memberikan kontribusi untuk bahan referensi bagi penelitian mendatang dengan tema yang sama. Dengan pembahasan terkait dengan remaja, secara tidak langsung artikel ini juga memberikan uraian mengenai kepribadian dan kecenderungan remaja dalam memandang suatu hal. Selain itu, tambahan pengetahuan yang hendak diberikan adalah mengenai dunia dakwah yang begitu luas dan bermacam macam.

Berkaitan dengan artikel ini, yang menjelaskan suksesnya Dunia digital dalam membawa perubahan yang begitu signifikan pada diri masing-masing orang. Beberapa penelitian yang berkaitan dengan tema ini, sebelumnya telah banyak digagas oleh cendikiawan dan para peneliti. Tema ini tentu sangat menarik, mengingat betapa sedang marak dunia digital itu menyebar dan terus menerus mengalami kemajuan hingga orang yang semakin banyak mengandrunginya. Salah satu penelitian terdahulu yang pernah digagas adalah Jurnal Sosioteknologi yang ditulis oleh Moch Fakhruroji dan Enjang Muhaemin berjudul "Sikap akademi si dakwah terhadap internet sebagai media dakwah". Penelitian tersebut membahas tentang pandangan akademisi terhadap internet yang dijadikan sebagai media dakwah, dalam hal ini media online berperan penting sebagai media dakwah. Hal tersebut dapat dilihat dari pemahaman responden yang relatif baik namun hal tersebut belum berbanding lurus dengan upaya mereka dalam mengoptimalkan internet sebagai media dakwah. Selain penelitian tersebut terdapat pula penelitian lain seperti salah $\mathrm{Al}$ hiwar Jurnal Ilmu dan Teknik Dakwah yang ditulis oleh Supriyadi Hadi Saputra yang membahas tentang "Persepsi masyarakat terhadap penyiaran dakwah islamiyah melalui televisi swasta di kota Banjarmasin". Hasilnya menunjukkan bahwa televisi swasta sebagai media penyiaran dakwah merupakan suatu pola baru dalam masyarakat, namun hal tersebut sebenarnya sudah ada sebelumnya. Dalam penyampaian dakwahnya pun masih diperlukan perbaikan yakni dengan memperbanyak dialog interaktifnya sehingga tercipta komunikasi dua arah. Dari kedua penelitian tersebut, masih terdapat suatu keingintahuan dari peneliti untuk mengetaui sejauh mana pengetahuan remaja tentang dakwah melalui media internet dan tanggapan mereka tentang dakwah tersebut. Berdasar atas hal tersebut maka, artikel ini akan mencoba kembali mengupas dengan judul berbeda, yakni "Perspektif remaja terhadap 
dakwah online studi empiris siswa MA Hasanuddin Siraman Kesamben Blitar".

Untuk memberikan penjelasan mengenai tema tersebut, penulis telah menggunakan Beberapa teori yang relevan agar dapat diunakan untuk menunjang artikel yang ada. Membicarakan masalah teori, banyak ahli yang memberikan definisi mengenai hal tersebut. Snelbecker dalam Moleong (2016:56), Berpendapat bahwasannya teori sebagai seperangkat proporsi yang berinteraksi secara sintaksasi(yaitu patuh terhadap aturan khusus yang dapat untuk dihubungkan dengan lainnya secara logis dengan data atas dasar pengamatan) dan memiliki fungsi sebagai sebuah wahana untuk meramalkan dan menjelaskan fenomena yang diamati. Sedang menurut Mark dan Goodson dalam Moleong (2016:56) memandang bahwasannya teori ialah sebuah aturan yang menerangkan megenai proporsi atau seperangkat proporsi terkait fenomenafenomena ilmiah yang dan terdiri atas representasi simbolik dari (1). Beberapa hubungan yang dapat diamati diantara beberapa kejadian (yang dapat diukur), (2) Mekanisme serta struktur yang disangka mendasari hubungan demikian, (3) Beberapa hubungan yang disimpulkan dan dimanifestasikan hubungan empiris apapun secara langsung.

Dengan adanya teori yang digunakan, maka akan ada dasar dalam berpikir dan mengontruksi tulisan ini. Adapaun bebarapa teoi yang digunakan untuk penulisan ini adalah teori yang berkaitan seputar dunia dakwah, remaja, teori perspektif dan beberapa penjelasan konseptual pelengkap lain.

Mengenai dunia online dan seputar internet Umi Aflaha dalam skripsi yang ditulis oleh Yigi Ridho Firdaus mengatakan bahwa internet dan media sosial (1) merupakan dua unsur yang disatukan dalam satu aplikasi yang mendukung sosialisasi sekaligus sebagai media informasi, baik sifatnya yang terbatas maupun tak terbatas. Internet semakin kesini, semakin merambah kedunia dakwah. Dakwah memiliki pengertian yang berasal dari bahasa arab. Yakni kata Da'a, yad'u, dan bentuk masdarnya lah yang menjadi asal muasal kata dakwah, yakni Da'watan yang berarti ajakan, seruan, atau panggilan. Sementara alquran juga ttelah menjelaskan pengertian dakwah sendiri pada surat yunus ayat 25, yang berarti Memanggil dan menyeru : " Allah menyeru (manusia) ke Darussalam (surga) dam memberikan petunjuk kepada orang yang dikehendaki-Nya kepada jalan yang lurus (Islam) ". Sementara menurut M. Isa Anshary dalam Zulkarnaini (2015) Dakwah merupakan menyampaikan seruan Islam, mengajak dan memanggil umat manusia agar menerima dan memercayai keyakinan dan pandangan hidup Islam. Mengacu atas beberapa pengertian dakwah dari ayat Al-quran maupun pendapat para ahli, maka artikel ini memberikan tolok ukur penelitian yang juga sesuai dengan teori yang ada.

Selanjutnya, berkaitan dengan teori remaja diambil dari Kata remaja berasal dari bahasa latin adolescere yang artinya tumbuh untuk mencapai kematangan atau dalam perkembangan menjadi dewasa (Ali.M dan Asrori.M, 2006 : 9). Remaja merupakan Usia dimana anak tidak lagi merasa di bawah tingkatan orang-orang yang lebih tua,melainkan berada dalam tingkatan yang sama, sekurang-kurangnya dalam masalah hak (dalam Hurlock, 1997).

Kemudian membicarakan mengenai persepsi pengertian yang dijadikan sebagai landasan adalah Leavitt dalam Sobur (2003: 445) yang menyatakan bahwa persepsi dalam arti sempit ialah penglihatan, 
bagaimana cara seseorang melihat sesuatu, sedangkan dalam arti luas ialah pandangan atau pengertian, yaitu bagaimana seseorang memandang atau mengartikan sesuatu. Persepsi merupakan hasil dari penghayatannya terhadap rangsangan (stimulus) yang berasal dari lingkungan.

\section{METODE PENELITIAN}

Pendekatan yang digunakan dalam artikel ini merupakan pendekatan kualitatif. Menurut kirk and Miller dalam (Pupu, 2009:2) yang dikutip dari buku Nasution mengungkapkan bahwa istilah kualitatif sebenarnya bermula dari pengamatan kualitatif yang dipertenangkan dengan penelitian kuantitatif. Adapun definisi dari metodologi kualitatif menurut mereka ialah tradisi tertentu dalam ilmu pengetahuan sosial yang secara fundamental bergantung pada pengamatan pada manusia dalam keabsahannya sendiri dan berhubungan dengan orang-orang tersebut dalam bahasannya serta dalam peristilahannya. Pendekatan kualitatif dalam penulisan ini, dipilih sebab lebih mudah untuk menguraikan hasil dan pembahasan kemudian. Juga menurut Bogdan dan Biklen dalam (Pupu, 2009:2) juga menjelasakan bahwa hasil daari penelitian kualitatif bersifat deskriptif berupa suatu ucapan atau tulisan dari perilaku orang orang yang diamati. Hasil dari artikel ini juga merupakan banyak dari tuturan dan pendapat masyarakat, sehingga pendekatan kualitatif dirasa sangat tepat. Kemudian untuk menyelaraskan dengan ppendekatan yang digunakan, jenis penelitian yang digunakan adalah deskriptif, menurut Tjutju Soendari penelitian deskriptif ini merupakan penelitian yang berusaha untuk mendeskripsikan suatu gejala, peristiwa, kejadian yang terjadi pada saat sekarang. Dalam penelitian deskriptif tidak diperlukan suatu administrasi juga pengontrolan terhadap suatu perlakuan. Sebuah penelitian deskriptif tidak memerlukan pengujian terhadap hipotesis tertentu, namun jenis penelitian ini akan memberikan gambaran secara apa adanya sesuai dengan variable yang diamati, gejala yang muncul atau juga keadaan yang ada. (Umat, 2020 : 32). Dalam artikel ini, Sumber penelitian yang digunakan oleh peneliti didapatkan melalui tiga cara yakni, Observasi, wawancara dan Dokumentasi dengan turun secara langsung ke lapangan untuk mengamati secara langsung kepada subjek penelitian. Observasi dijadikan sebagai sumber penelitian primer yang digunakan sebagai masukan utama, terhadap datadata yang akan digunakan. Observasi akan dilakukan di lapangan secara langsung di MA Hasanuddin Siraman dan juga lingkungan sekitar sekolah, juga akan mengobservasi halaman web serta situs media online, serta channel yang menyajikan dakwah online. Selain observasi sebagai sumber primer, peneliti juga akan menggunakan teknik wawancara untuk mendapatkan data. Wawancara merupakan kegiatan tanya jawab dengan seseorang yang dilakukan untuk dimintai keterangan atau pendapatnya mengenai suatu hal.

Adapun Teknik pengumpulan data yang akan digunakan dalam artikel ini ialah teknik Triangulasi data. Triangulasi merupakan pendekatan yang multimetode saat mengumpulan data/hasil analisis data. Menurut Moleong (2016:330) mengemukakan bahwasannya triangulasi adalah teknik pemeriksaan keabsahan data yang memanfataakan sesuatu yang lain diluar data itu untuk keperluan pengecekan atau sebagai penanding terhadap data itu. Teknik dari triangulasi yang paling sering digunakan ialah pemerikasaan melalui sumber lainnya. Ide dasarnya adalah bahwa 
fenomena yang diteliti dapat dipahami dengan baik sehingga kebenaran yang diperoleh juga akan akurat ketika ditinjau dari berbagai sudut pandang. (Umat, 2020:38).

Dalam artikel ini, peneliti memfokuskan diri menjadi seorang peneliti, sehingga menetapkan masalah sebagai fokus yang hendak diambil. Terkait dengan masalah yang akan dikaji dan diteliti oleh peneliti, ialah mengenai persepsi remaja terhadap dakwah online. Hal tersebut berakar dari fenomen yang kini banyak terjadi di kalangan remaja dan masyarakat yakni tingginya penggunaan media online dan internet uuntuk mengakses dan memudahkan segala aktifitas dan kebutuhan mereka. Tentu saja jika menengok pada beberapa decade kebelakang, hal ini menjadi sangat fenomenal dimana seluruh kebutuhan telah mampu dioperasikan oleh robot dan juga oleh media.

Dunia dakwah yang menjadi fokus dalam artikel inilah yang kemudian juga terpapar akibat dari meluasnya teknologi internet. Dakwah yang semula secara konvensional disampaikan dengan bertatap muka secara langsung dan mendatangkan kyai-kyai besar dalam majlisnya, kini tidak lagi demikiann, dakwah telah menyesuaikan diri dengan perkembangan zaman yang ada. Dakwah mencoba menjadi modern dengan terjun di dunia digital. Hal ini tentu salah satu usaha untuk menunjukkan diri bahwa dakwah adalah suatu hal yang cukup dinamis dan mampu memenuhi kebutuhan masyarakat. Remaja sebagai tokoh yang memiliki peran akses cukup tinggi dalam mengakses dunia digital internet khusunya menarik perhatian peneliti untuk meneliti mengenai persepsi remaja terhadap dakwah online yang sudah banyak tersebar dan diakses dalam masyarakat luas. (Umat, 2020: 41)
Adapun lokasi penelitian artikel kali ini dipilih di MA Hasanuddin. Hal tersebut dikarenakan di MA Tersebut sudah hampir seluruh siswa sudah menggunakan media sosial dan juga digital untuk menunjang kegiatan sehari-hari. Siswa di sekolah tersebut juga telah sedikit banyak mengetahui mengenai dunia dakwah online yang hendak peneliti tanyakan. Selain itu, MA Hasanuddin Siraman juga memiliki siswa dan lingkungan pendidikan yang bersifat Islami dan sangat ramah, sehingga peneliti tertarik untuk melakukan penelitian di daerah tersebut.

\section{HASIL dan PEMBAHASAN}

Kata remaja berasal dari bahasa latin adolescere yang artinya tumbuh untuk mencapai kematangan atau dalam perkembangan remaja(Ali M. dan Asrori M., 2006 : 9). Psikologi menyatakan bahwa remaja adalah suatu periode transisi dari masa awal anakanak menuju masa dewasa dengan rentang usia antara 10- 12 tahun hingga usia 18-22 tahun. " $Y$ a, namanya remaja pasti harus mempersiapkan dirilah, pokok harus pinter-pinter menyaring mana yang baik dan mana yang ndak baik. Harus cerdas juga. Remaja masib labil juga seperti kami jadi memang harus pandai-pandai intinya." Dan "Remaja tentu pati punya peran, juga harus bisa menyikapi secara baik."

Dari pernyataan tersebut dapat diketahui bahwa seorang remaja harusnya berperilaku dan menyikapi perkembangan yang ada. Remaja tidak hanya sekedar masa namun juga sikap yang harus tegas dan berani serta cerdas untuk menentukan arah kedepan.

Penggunaan internet hampir sudah dilakukan oleh sebagian remaja di MA Hasanuddin siraman. Internet bertindaksebagai penolong dalam 
memenuhi informasi pembelajaran. Selain itu, adanya game online juga menjadi hiburan tersendiri bagi mereka di tengah-tengah kepenatan belajar.

Di sisi lain, tersebarnya link atau website penyedia konten tak layak tonton dan rentannya akan berita palsu atau hoax yang muncul dalam internet seakan menjadi dua sisi yang kontradiktif adanya. Syifa Nurjannah, siswa kelas XII IPA MA Hasanuddin mengatakan bahwa hal tersebut merupakan PR tersendiri bagi remaja agar pandai dalam menyaring informasi yang ada.

Seperti yang telah kita ketahui bahwa internet telah berhasil merambah ke segala aspek kehidupan termasuk dunia dakwah. Istiah dakwah bukanla ha lasing bagi siswa-siswi MA asanuddin siraman karena hal tersebut sudah sangat erat dengan kehidupan mereka. Đakwah ya ajakan, ngjak yang lain untuk berbuat baik, hal-hal kecil seperti mengingatkean untuk salat, membuang sampah pada tempatnya, mengajak ngaji, sholawatan, ya itu sudah bentuk dakwah. Jadi sudah ndak asing lagi, kita juga sering melakukan hal-hal kayak gitu."

Pernyataan tersebut mengindikasikan bahwasannya dakwah bukan hanya sekedar ceramah satu dua arah, namun juga berupa perilaku seharihari untuk mengajak melakukan kebaikan. Mereka biasa memahami al tersebut dengan istilah "Amar ma'ruf nahi munkar."

Dakwah dapat disampaikan melalui banyak cara yakni dengan seruan bil-lisan yang berupa ceramah dan denagn menggunakan al-kitabah atau tulisan.selain itu, dakwah juga dapat berupa perbuatan nyata (dakwah bil-hall) yang tercermin dalam bentuk pendidikan ekonomi, sosial, politik, dan lain sebagainya. Dari penjelasan tersebut banyak siswa (remaja) di MA Hasanuddin dominan memandang dakwah merupakan sebuah seruan billisan karena lebih familiar dan lebih mudah untuk dilakukan.

Setelah mengetahui terlebih dahulu bagaimana pandangan para remaja MA Hasanuddin mengenai dunia digital, dakwah, serta remaja dan karakternya, maka peneliti mencoba untuk mengetahui secara lebih implisit mengenai persepsi mereka terhadap dakwah online yang telah beredar di berbagai platform sosial media.sebagai seorang siswa juga remaja mereka mengaku merupakan pengguna aktif sosial media dan juga pern mengakses dakwah online, terlebih dari aplikasi youtube yakni aplikasi penyedia video online. Berdasar atas tontonan yang mereka lihat muncul banyak sekali persepsi dan pandangan yang muncul. Berikut beberapa di antaranya :

\section{Dakwah online baik}

Dikatakan baik, sebab di zaman yang semakin sibuk ini menjadikan mereka tidak punya banyak luang untuk mendatangi majlis taklim guna menimba ilmu agama. Dakwah online ini muncul sebagai solusi bagi pihak-pihak yang berkepentingan demikian. "ya, dakwah online juga baik mbak. Ini kan syiar agama kalau dengan media online seperti ini kan jadi lebih luas syiar agamanya" dan "Enak si mbah, bisa belajar di internet kan mudah." dan "Ya itukan mempermudah bagi seseorng, kalau mau dengerin dakwah gak pelu kumpul di masjid dulu."

\section{Kurang tepat karena beda aliran/madzhab}

Dengan adanya kemudahan dalam mengakses dakwah online dengan menggunakan internet, tidak semua siswa MA Hasanuddin Siraman berpikiran demikian. Seperti yang kita ketahui bahwa 
Islam memiliki banyak aliran/madzhab yang berbeda atau bahkan bertolak belakang antara yang satu dengan yang lain. Menurut siswa di MA Hasanuddin Siraman, hal ini menjadikan dakwah dengan media online akan sulit dan kurang tepat dilakukan. "ya, mesti nanti banyak yang tidak sesuai to, kan tiap kyai dan aliran punya kepercayaan tersendiri, punya kitabnya tersendiri. Kalau ndak manut kitab kan bisa saja terjerumus dalam hal yang tiak baik." dan "Wah, kalau dakwahnya online nanti pasti beda mbak antara NU sama Muhammadiyah. Pasti ndak cocok." dan "Kan setiap orang punya guru masing-masing, mbak. Jadi takut kalau terjadi salah paham nanti kealau dakwahnya secara online."

\section{Kurang tepat karena dapat dimasuki oleh hoax}

Menurut kamus besar Bahasa Indonesia, Hoax merupakan informasi bohong. Menurut siswa MA Hasanuddin Siraman, dakwah melalui situs-situs online memiliki kemungkinan besar akan penyebaran hoax di dalamnya, sebab kita tidak mengetahui sumber dari informasi dan dakwah tersebut. "ya pasti kan nanti bisa jadi ada hoax dalam penyampaian dakwah, kalau yang menerima dakwah tersebut orang awam yang masih baru belajar agama kan bahaya juga.”

Kasus hoax muncul ditujukan untuk membelokkan kepercayaan dan menghimpun kesalahpahama agar terjadi perseteruan dan perpecahan. Hal tersebut memungkinkan dakwah online menjadi sasaran empuk bagi pihak yang tidak menyukai Islam untuk membenturkan dan memecah belah Islam dengan cara halus.

\section{Kurang efektif}

Menurut pandangan dari beberapa siswa, dakwah online sebenarnya tidak efektif untuk dilakukan. Hal tersebut dikarenakan media online sifatnya tidak langsung dan bebas akses.selain itu, para siswa juga kerap kali menyebutkan bahwasannya dalam dakwah tidak hanya ilmu saja yang kita gali, namun juga barokahnya. "ya, kalau lihat dan dengerin langsung kan bakal dapat barokah juga mbak."

Dakwah yang disampaikan pada remaja tidak semua dapat diterima dan dipahami dengan baik. Terdapat tema-tema khusus yang harus sesuai dengan usia dan karakter mereka. Beberapa siswa di MA Hasanuddin memiliki ketertarikan pada beberapa tema dakwah, diantaranya :

\section{Sejarah atau sirah nabi}

"kalau belajar tentang sejarah dan kisah nabi, kita bisa mendalami kehidupanna nabi lebih luas." serta "Kalau saya ya, tentang sejarah suka." Dan "Sejarah Islam sib, mbak kealau saya"

Dari beberapa pendapat tersebut, remaja di MA Hasanuddin Siraman menyukai dakwah mengenai sejarah Nabi Muhammad SAW dan sejarah Islam. Dengan mempelajari sirah perjalanan beliau kita menjadi lebih tahu mengenai akhlak dan kepribadian beliau sehari-hari dan mengimplementasikannya. Selain itu, pembahasan mengenai sejarah Islam menjadikan kita lebih tahu tokoh-tokoh di balik kejayaan Islam dan mengambil hikmah berharga darinya.

\section{Remaja dan akhlak}

Menurut kamus besar bahasa Indonesia, akhlak berarti budi pekerti atau kelakuan. Dakwah dengan tema akhlak da remaja akan sangat bermanfaat bagi remaja sebagai tuntunan dalam mengerjakan sesuatu. Salah satu jurnal dari Nunung Unayah dan muslim sabarisman menjelaskan bahwa terdapat kasus pembegalan motor dan perampokan 
di Depok dan Tangerang serta daerah lainnya dengan beberapa orang pelakunya masih berusia remaja. "Akblak itu balutama, baik dan patut diutamakan, harus diajarkan." Serta "Akblak itu penting untuk dipahami, mbak, remaja juga begitu kan kita ini remaja jadi ya harus mengetahui tentang remaja." Dan "Akhlaklah, mbak, saya suka dan penting juga."

Akhlak memiliki peran strategis dalam membangun karakter remaja dan menuntun mereka ke arah yang lebih baik. Dengan mempelajari mengenai dirinya sendiri dan akhlak yang harus dimiliki, kehidupan remaja akan semakin terarah.

\section{Hidup dan motivasi sehari-hari}

Beberapa siswa di MA Hasanuddin siraman menaruh perhatian dan ketertarikan terhadap motivasi kehidupan sehari-hari. Motivasi menurut Kamus Besar Bahasa Indonesia berarti dorongan yang timbul dari diri seseorang secara sadar atau tidak sadar untuk melakukan sesuatu tindakan dengan tujun tertentu.namun, konsep pemikiran siswa yang dimaksud adalah motivasi lisan secara sadar untuk menumbuhkan semangat dalam melakukan kebaikan. "Kalau saya suka dakwah itu yang isinya memotivasi terus soal masa depan biar sukses itu gimana gitu lho, mbak." serta "Saya suka yang memotivasi gitu mbake dakwahnya."

Dakwah dengantema motivasi juga baik untuk persiapan diri bagi remaja sebagai bentuk dorongan untuk senantiasa melakukan kebaikan. Setelah melakukan pertimbangan mengenai tema yang disukai remaja, maka selanjutnya barulah peneliti memfokuskan diri untuk mengetahui model serta metode dakwah yang disukai oleh remaja. Berikut peneliti mendapatkan beberapa jawaban mengenai hal tersebut.

\section{Dakwah dan humor}

Humor menurt Kamus Besar Bahasa indonesa berarti sesuatu yang lucu. Menurut sebagian besar informan yang berhasil diwawancarai oleh peneiti, dakwah akan semakin menarik bila diselipi dengan humor. "Ya, kalau dakwah yang baik dan membuat tertarik itu unsurjenakanya sib mbal." Dan "Ya, pokoknya dakwah yang lucu yang dapat mencairkan suasana biar gak pada tegang dan semakin tertarik lagi dalam bidang dakwah."

Humor merupakan senjata ampuh pengusir rasa bosan saat mendengarkan dakwah. Dengan menggunakan selingan humor dalam mnyampaikan dakwah para audiens utamanya remaja dapat menerima dan menikmati dakwah yang disampaikan.

\section{Dakwah secara langsung/tatap muka}

Berdasar atas wawancara yang telah peneliti lakukan, dari 11 orang siswa dan seorang Guru MULOK mengatakan bahwasannya dakwah akan lebih baik untuk disampaikan secara langsung dan bertatao mukasbagian besar siswa berpikiran bahwa dengan bertemu langsung dengan pendakwah ilmu dapat tersampaikan dan keberkahan masyaayikh akan didapatkan. "Dakwah itu enaknya langsung ketemu pendakwahnya, kan seneng terus lebih barokah lah mesti." Serta, "Kalau saya pribadi, sebagai guru ya lebih menganjurkan dan menyukai dakwah yang disampaikan scara langsung daripada dengan menggunakan media online, kalau langsung itu, tentu saja barokahnya dapat dan para penonton bisa lebih paham penjelasan dari pendakwahnya, jadi lebih efektif jugalah.”

Dari beberapa pernyataan tersebut dapat diketahui bahwa dakwah konvensional dengan tatap muka lebih efektif daripada dakwah online. Hal 
tersebut dikarenakan penyampaian dakwah dengan tatap muka langsung dinilai lebih komunikatif dimana pendakwah dapat berinteraksi langsung dengan audiens.

\section{KESIMPULAN}

Remaja merupakan seseorang yang telah memasuki masa peralihan dari masa kanak-kanak menuju masa dewasa. WHO menyatakan bahwa remaja merupakan penduduk dalam rentang usia 1019 tahun. Masa remaja merupakan masa yang penting dalam kehidupan karena terdapat beberapa perubahan dalam diri remaja yakni dalam hal kepribadian dan pemikirannya. Secara tidak langsung kepribadian seseorang dapat berpengaruh pada pemikiran yang diutarakan. Hal tersebut dapat dilihat dari cara ia memberikan persepsi terhadap sesuatu.

Masa remaja bukan hanya sekedar masa karena terdapat tantangan tersendiri di era milenial seperti sekrang ini. Seperti yang kita ketahui bahwa perkembangan internet telah merambah ke segala aspek kehidupan termasuk dalam dunia dakwah. Berdasar pada penelitian yang telah dilakukan dapat diketahui bahwa dakwah online memiliki sifat yang baik karena dengan adanya dakwah di media online semakin mempermudah pengguna internet dalam mencari informasi keagamaan di tengah kesibukan zaman. Namun, di sisi lain banyaknya aliran atau mazhab dalam Islam menjadikan dakwah online kurang tepat untuk disebarluaskan. Adanya perbedaan aliran dalam dakwah online dapat berdampak pada munculnya ketidakcocokan pemahaman, sehingga akan memunculkan suatu perbedaan informasi antara aliran yang dianut dengan informasi yang didapatkan melalui dakwah online.
Selain itu, rentannya dakwah online akan hoax atau berita palsu juga menjadi alasan ketidaktepatan media online sebagai solusi penyebaran dakwah. Berita palsu tersebut ditujukan untuk mengubah kepercayaan dan menghimpun kesalahpahaman antarsesama agar tercipta suatu perseteruan dan terpecah belahnya persatuan yang telah ada. Hal-hal tersebut menjadikan dakwah online kurang efektif untuk diterapkan. Kurangnya tatap muka langsung dan interaksi antarsesama dalam dakwah online juga berpengaruh terhadap pemahaman pendengar dakwah. Hal tersebut sangatlah jauh berbeda dengan dakwah konvensional dengan tatap muka langsung yakni dalam hal pemahaman ilmu.

Dakwah yang disampaikan pada remaja tidak sepenuhnya dapat diterima dan dipahami dengan baik. Berdasar pada penelitian yang telah dilakukan terdapat beberapa tema yang diminati oleh remaja, salah satunya yaitu sejarah atau sirah Nabi Muhammad SAW. Dengan mempelajari hal tersebut, remaja dapat mengetahui rangkaian perjalanan dalam Islam dan mengambil hikmah berharga darinya. Selain itu, sifat Nabi Muhammad SAW yang mulia dapat menjadi benteng diri untuk tetap berada di jalan lurus dan mempertahankan persatuan umat.

Selain itu, remaja juga minat terhadap dakwah mengenai remaja dan akhlak. Sifat remaja yang cenderung labil akan dengan mudah terpengaruh dengan hal baru yang akan berdampak pada kegoyahan akhak yang dimliki. Itulah mengapa dakwah mengenai remaja dan akhlah menjadi pembahasan yang penting. Dengan mempelajari dirinya sendiri serta akhlak yang harus dimiliki, remaja dapat lebih terarah dalam menjalani kehidupan. 
Pembahasan mengenai kehidupan dan motivasi sehari-hari juga menjadi tema dakwah yang diminati oleh remaja. Dengan mempelajari kehidupan dan motivasi diri, semangat remaja untuk melakukan kebaikan akan terus tercermin dalam kehidupan sehari-harinya.

Dalam penyampaian dakwah, model atau metode berdakwah menjadi unsur penting guna menarik minat remaja dalam dunia dakwah. Berdasar pada penelitian yang telah kami lakukan, terdapat beberapa model dakwah yang diminati remaja, yaitu tatap muka langsung dengan selingan humor. Dengan menggunakan metode tersebut keberkahan dalam dakwah dapat lebih tersampaikan dan pemahaman pendengar dapat dipertanggungjawabkan. Selingan humor dalam dakwah menjadikan suasana dakwah lebih cair sekaligus sebagai senjata ampuh pengusir rasa bosan saat mendengarkan dakwah.

\section{DAFTAR PUSTAKA}

Ali, M. \& Asrori, M. (2006). Psikologi Remaja,Perkembangan Peserta Didik. Jakarta: Bumi Aksara.

Amin, Samsul Munir. (2014). Sejarah Dakwah. Jakarta: Amzah

Daulay, Haidar Putra, Nurgaya Pasa. (2012). Pendidikan Islam Dan Mencerdaskan Bangsa. Jakarta : Rineka Cipta

faizah, Lalu Muchsin Effendi. (2009). Psikologi Dakwah. Jakarta: Kencana

Farozin, Muh. (2004). Pemahaman Tingkah Laku. Jakarta : Rineka Cipta

Hadi, Sutrisno. (2000). Psikologi Pendidikan. Yogyakarta: Andi

Kumparan. (2017). Lebih Efektif Mana, Dakwah Online Atau Tatap Muka. (Online). Diakses pada 28 Desember 2019

Marzuki. (2015). Pendidikan Karakter Islam. Jakarta: Amzah.
Moleong, Lexy J. (2016). Metode penelitian Kualitatif Edisi Revisi. Bandung: Remaja Rosdakarya

Mudjia dan Rahardjo. (2010). Majalah onlime kampus GEMA Media Informasi dan kebijakan kampus). (Online). Diakses pada 29 Desember 2019.

Mulyana, H. F .(2013). Manajemen Pendidikan Karakter. Jakarta: Bumi Aksara

Qomari, Rohmad. (2009). Teknik Penelusuran Analisis Data Kuantitatif Dalam Penelitian Kependidikan. Jurnal Insania. Vol. 14, No. 3, 1-11.

Rahmat, Pupu Saiful. (2009). Penelitian Kualitatif. Jurnal Equilibrium, Vol. 5, No. 9, 1-8.

Santrock, John W. (2003). Perkembangan Remaja. Jakarta: Erlangga.

Sarwono, Sarlito W. (2004). Psikologi Remaja. Jakarta: PT. Raja Grafindo Persada

Sjarkawi. (2009). Pembentukan Kepribadian anak : peran moral intelektual, emosional, dan sosial sebagai wujud integritas membangun jati diri. Jakarta: Bumi Aksara

Unayah, Nunung \& Sabarisman, Muslim. (2015). Fenomena Kenakalan Remaja Dan Kriminalitas. Jurnal Sosio Informa. Vol. 1, No. 02, 121140.

Ventura, E. (2011). Mengelola Konten di Era 2.0 Jurnal Dewan Pers, Edisi No. 4, 25-34.

Zulkarnaini. (2015). Dakwah Islam Modern. Jurnal Risalah, Vol. 26, No. 3, 151-158 
